\title{
Pengaruh Model Pembelajaran Somatic, Auditory, Visualization, Intellectualy Berbantuan Multimedia Terhadap Kompetensi Pengetahuan IPA Kelas V
}

\author{
N. M. D. D. Lestari \\ Jurusan Pendidikan Dasar, Universitas Pendidikan Ganesha, Singaraja, Indonesia \\ diahlestaridw@gmail.com
}

I K. N. Wiyasa

Jurusan Pendidikan Dasar, Universitas Pendidikan Ganesha, Singaraja, Indonesia ngrh.wiyasa@undiksha.ac.id

I. B. S. Manuaba

Jurusan Pendidikan Dasar, Universitas Pendidikan Ganesha, Singaraja, Indonesia idabagussurya.manuaba@undiksha.ac.id

\begin{tabular}{l} 
A R T I C L E I N F O \\
\hline Article history: \\
1 Juli 2020 Received in \\
revised form \\
30 Agustus 2020 \\
Accepted 28 September 2020 \\
Available online \\
30 September 2020 \\
Kata Kunci: \\
SAVI, multimedia, \\
kompetensi pengetahuan \\
IPA \\
Keywords: \\
SAVI, Multimedia, science \\
knowledge competence
\end{tabular}

A R T I C L E I N F O

1 Juli 2020 Received in revised form

30 Agustus 2020

Available online

knowledge competence

\begin{abstract}
AB S T R A K
Penelitian ini bertujuan untuk menganalisis pengaruh model pembelajaran Somatic, Auditory, Visualization, Intellectualy (SAVI) berbantuan multimedia terhadap kompetensi pengetahuan IPA Kelas V. Penelitian ini merupakan penelitian eksperimen semu dengan rancangan Non-equivalen Posttest Only Control Group Design. Populasi dalam penelitian ini adalah kelas V SD yang berjumlah 226 siswa, sedangkan sampel berjumlah 76 siswa ditentukan dengan teknik cluster random sampling. Pengumpulan data kompetensi pengetahuan IPA dilakukan dengan memberikan posttest dalam bentuk tes objektif yang berjumlah 36 butir. Data yang diperoleh dianalisis menggunakan uji-t polled varians. Berdasarkan hasil analisis diperoleh thitung $=4,51$ yang kemudian dibandingkan dengan ttabel pada taraf signifikansi 5\%
\end{abstract} dengan $\mathrm{dk}=74$ yaitu 2,00. Hasil analisis hipotesis menunjukkan thitung $=4,51>$ ttabel $=$ 2,00, sehingga $\mathrm{H} 0$ ditolak dan Ha diterima. Jadi, dapat disimpulkan bahwa terdapat pengaruh yang signifikan model pembelajaran SAVI berbantuan multimedia terhadap kompetensi pengetahuan IPA kelas V SD. 


\section{PENDAHULUAN}

Pendidikan merupakan suatu upaya yang dapat dilakukan untuk meningkatkan kualitas sumber daya manusia. Sistem pendidikan memfokuskan pengembangan kemampuan yang diarahkan pada kecakapan hidup (life skill) sehingga dikemudian hari dapat menopang kesejahteraan dirinya sendiri, keluarga serta masa depannya secara layak di masyarakat (Shoimin, 2014).

Pada pelaksanaan pendidikan, kurikulum menjadi acuan bagi lembaga pendidikan formal di Indonesia. Kurikulum yang berlaku di Indonesia saat ini adalah Kurikulum 2013, dengan pelaksanaan pembelajaran berpusat pada siswa dalam memperoleh pengalaman belajar. Kurikulum 2013 dilaksanakan dengan memadukan beberapa muatan materi dalam sebuah tema yang disebut dengan tematik terpadu. Salah satu muatan materi pada pembelajaran tematik adalah Ilmu Pengetahuan Alam (IPA). IPA merupakan suatu ilmu yang mempelajari tentang diri sendiri, lingkungan, dan alam semesta secara utuh sehingga berkaitan langsung dengan kehidupan sehari-hari (Ramadhan et al., 2016). IPA merupakan ilmu yang mempelajari tentang fenomena berupa fakta dan hubungan sebab akibat terhadap sesuatu yang terjadi di alam (Candra et al., 2017). Jadi, dapat disimpulkan bahwa IPA adalah suatu ilmu yang mempelajari peristiwa alam yang didasarkan pada kegiatan ilmiah secara sistematis untuk mencari tahu suatu kebenaran.

Pada proses pembelajaran terdapat kompetensi-kompetensi yang harus dicapai siswa, yang diantaranya adalah kompetensi sikap, pengetahuan dan keterampilan. Adapun salah satu kompetensi yang harus dikuasai siswa dalam proses pembelajaran adalah kompetensi pengetahuan. Pengetahuan itu sendiri diartikan sebagai semua hal yang diketahui oleh manusia (Samatowa, 2016). Jadi, kompetensi pengetahuan dalam pembelajaran merupakan sebuah kemampuan untuk memahami materi pelajaran berdasarkan pengetahuan yang dimiliki siswa. Penilaian kompetensi pengetahuan dilakukan dengan mengukur penguasaan pada dimensi pengetahuan serta berbagai tingkat proses berpikir atau jenjang kognitif. Jadi, dapat disimpulkan bahwa kompetensi pengetahuan IPA adalah suatu kemampuan dalam menguasai konsep atau pengetahuan yang berkaitan dengan alam semesta beserta isinya sebagai perubahan tingkah laku setelah melakukan kegiatan belajar.

Pada kenyataannya muatan materi IPA masih dianggap sulit oleh sebagian siswa, baik di tingkat SD maupaun sekolah menengah. Anggapan itu dibuktikan dengan perolehan hasil ujian akhir sekolah yang dilaporkan oleh Departemen Pendidikan Nasional yaitu masih jauh dari standar yang diharapkan (Susanto, 2016). Padahal penguasaan kompetensi pengetahuan IPA sangat penting mengingat muatan materi dalam IPA sangat berkaitan dalam kehidupan sehari-hari. Sejalan dengan pendapat Samatow (2016) yang menyebutkan beberapa alasan muatan materi IPA dibelajarkan di SD, yaitu diantaranya, (1) IPA bermanfaat bagi suatu bangsa, sebab kesejahteraan bangsa diukur dari pencapaian teknologi yang dimiliki. Teknologi dijadikan sebagai tulang punggung pembangunan negara. Suatu teknologi tidak dapat berkembang pesat apabila tidak didasari oleh pengetahuan dasar yang memadai, yaitu berkaitan dengan IPA; (2) IPA memberikan kesempatan kepada siswa untuk berpikir kritis dengan dihadapkan pada masalah, yakni siswa menemukan sendiri, menyelidiki masalah serta berlatih memecahkan masalah tersebut melalui kegiatan-kegiatan ilmiah; (3) IPA tidak semata-mata bersifat hafalan karena dibelajarkan melalui percobaan. Dalam hal ini siswa terlibat langsung dalam pembelajaran sehingga dapat membangun pemahaman terhadap suatu konsep, bukan 
sekedar menghafalkan teori; (4) IPA mempunyai nilai-nilai pendidikan, yaitu mengembangkan potensi yang dapat membentuk kepribadian siswa secara keseluruhan, bukan hanya dari segi pengetahuannya, tetapi juga sikap dan keterampilan. Selain itu, IPA juga merupakan salah satu bagian dari pendidikan yang berpotensi dan berperan penting dalam menyiapkan sumber daya manusia yang berkualitas (Adnyana et al., 2017).

Susanto (2016) menyebutkan secara umum tujuan logis muatan materi IPA di SD yaitu antara lain, (1) memperoleh keyakinan terhadap anugerah Tuhan Yang Maha Esa berdasarkan keberadaan, keindahan, dan keteraturan alam ciptaanya; (2) mengembangkan pengetahuan dan pemahaman terhadap konsep-konsep IPA yang bermanfaat dan dapat diterapkan dalam kehidupan sehari-hari; (3) mengembangkan sikap ilmiah seperti rasa ingin tahu, sikap positif dan kesadaran tentang adanya hubungan yang saling mempengaruhi antara IPA, lingkungan, teknologi, dan masyarakat; (4) mengembangkan keterampilan proses untuk menyelidiki alam sekitar, memecahkan masalah, dan membuat keputusan; (5) meningkatkan kesadaran untuk memelihara, menjaga, dan melestarikan lingkungan; (6) menghargai alam dan segala keteraturannya sebagai salah satu ciptaan Tuhan; (7) memperoleh bekal pengetahuan, konsep, dan keterampilan IPA sebagai dasar untuk melanjutkan pendidikan ke jenjang selanjutnya.

Mengingat pentingnya muatan materi IPA yang seharusnya digemari dan dipahami dengan baik oleh siswa, namum kenyataannya dianggap sulit. Berdasarkan hasil observasi di SD Negeri Gugus Dr. Soetomo Denpasar Selatan menunjukkan bahwa masih banyak siswa yang pasif dalam proses pembelajaran, tidak mau bertanya ketika mengalami kesulitan belajar maupun menggali informasi lebih dalam selain menerima penjelasan dari guru, cepat merasa bosan dengan menunjukkan sikap lain-lain atau mengganggu teman, menganggap sulit muatan materi IPA dan cepat lupa dengan materi yang telah dipelajari sebelumnya. Selain itu, saat diskusi kelompok kebanyakan siswa hanya mengandalkan teman yang lebih pintar sehingga siswa lainnya kurang aktif dalam berpartisipasi. Hal tersebut menunjukkan masih banyak siswa belum mampu mengembangkan keterampilan berpikir kritis, terutama dalam menganalisis dan memecahkan masalah. Kurang percaya diri saat menjawab pertanyaan, serta konsentrasi siswa mudah terpecah. Masalah-masalah tersebut berdampak pada kompetensi yang seharusnya dicapai oleh siswa. Permasalahan yang terjadi di sekolah yaitu muatan materi IPA sulit dipahami karena materi yang terlalu banyak menghafal. Hal tersebut sesuai dengan pendapat Karwati (2018) rendahnya hasil belajar IPA disebabkan oleh kurangnya keaktifan siswa seperti jarang muncul pertanyaanpertanyaan maupun pendapat dari siswa dalam proses pembelajaran yang menyebabkan guru menarik kesimpulan bahwa siswa telah memahami materi pembelajaran. Disamping itu, hasil belajar IPA masih berada di bawah rata-rata disebabkan oleh beberapa hal, yaitu proses pembelajaran terjadi satu arah atau hanya terpaku pada guru, sementara siswa hanya sebagai penerima materi sehingga pembelajaran menjadi pasif serta menganggap materi IPA identik dengan hafalan, bukan pemahaman (Sihwinedar, 2015). Hal serupa juga dijelaskan oleh (Budiyanti \& Khairunnisa, 2019), bahwa perilaku siswa dalam belajar IPA di SD masih bersifat menghafal teori untuk mendapat nilai yang baik pada ranah kognitif. Kegiatan menghafal tersebut mengakibatkan siswa tidak memahami konsep IPA yang sesungguhnya. Hal lain yang menjadi masalah adalah kegiatan siswa dalam pembelajaran itu sendiri, termasuk kurangnya variasi dalam pembelajaran yang menuntut keterlibatan siswa secara aktif dalam belajar. Padahal seharusnya muatan materi IPA diarahkan pada kegiatan yang dapat memberikan pengalaman langsung kepada siswa, yaitu belajar dengan 
melakukan (learning by doing). Melalui pengalaman yang diperoleh siswa dapat memahami konsep-konsep yang dipelajari, tidak hanya sebatas menghafal teori. Kegiatan belajar IPA di SD sebaiknya dilakukan dengan penyelidikan sederhana, tidak sebatas menghafal konsep-konsep IPA, melalui kegiatan pengamatan, diskusi, pemecahan masalah sehingga dapat menumbuhkan sikap ilmiah dan kemampuan berpikir kritis (Agustino et al., 2017). Pentingnya penguasaan terhadap kompetensi pengetahuan IPA tidak hanya sebagai syarat untuk melanjutkan ke jenjang yang lebih tinggi, tetapi juga dapat memanfaatkan ilmu tersebut untuk memecahkan masalah yang terjadi di lingkungan sekitar (Setianingsih, 2019).

Kesenjangan antara kenyataan yang terjadi di lapangan dan kondisi ideal yang diharapkan tentunya berdampak pada kompetensi pengetahuan IPA siswa yang belum optimal. Berbagai permasalahan dalam pembelajaran yang terjadi di kelas, baik dari siswa, metodelogis maupun permaslahan akademik lainnya secara langsung maupun tidak langsung memiliki implikasi terhadap capaian kompetensi siswa (Arisantiani, 2017). Pencapaian kompetensi dipengaruhi oleh dua faktor, yaitu faktor dalam diri siswa (internal) dan faktor luar diri siswa (eksternal). Faktor internal meliputi minat, motivasi diri, kebiasaan, dan kecerdasan. Sedangkan, faktor eksternal meliputi cara mengajar guru, dukungan keluarga, dan lingkungan sekitar. Guru sebagai faktor pendukung keberhasilan pembelajaran berperan penting membantu siswa mencapai kompetensi yang diharapkan.

Dari pemaparan tersebut, salah satu rekomendasi yang dapat dilakukan untuk mengatasi masalah terhadap kompetensi pengetahuan IPA adalah dengan mengadakan inovasi dan variasi pembelajaran. Inovasi desain pembelajaran dapat dilakukan dengan menerapkan model dan media pembelajaran yang dapat mengaktifkan partisipasi siswa dalam belajar (Pradnyana et al., 2017). Salah satu inovasi yang dapat dilakukan adalah menerapkan model pembelajaran SAVI berbantuan multimedia. Model pembelajaran SAVI merupakan salah satu model pembelajaran yang menganut aliran kognitif modern dengan menyatakan kegiatan belajar yang baik yaitu dengan melibatkan emosi, gerak fisik atau alat-alat indra dan aktivitas intelektual, serta menghargai perbedaan gaya belajar setiap siswa (Indrawan et al,. 2018). Model pembelajaran SAVI menekankan cara belajar berdasarkan aktivitas dengan memanfaatkan seluruh indra dan pikiran dalam aktivitas pembelajaran (Putra et al., 2016). Model pembelajaran SAVI mempunyai empat unsur seperti yang dikutip pada Meier (2002), yaitu somatic, auditory, visualization, intellectualy. Adapun penjelasan lebih lanjut dari masing-masing unsur yang diantaranya, (1) Somatic, yaitu belajar dengan melibatkan indra peraba, kinestetik, aktivitas fisik dan menggerakkan badan sewaktu-waktu, mengalami dan melakukan sesuatu, seperti memperagakan suatu proses, melakukan simulasi dan kegiatan percobaan; (2) Auditory, yaitu belajar dengan memanfaatkan indra pendengaran, termasuk mendengar dan berbicara seperti mendengarkan cerita, menyimak, mengungkapkan pendapat, bertanya, mempresentasikan hasil diskusi, bercerita dan berdialog; (3) Visualization, yaitu belajar dengan melihat dan mengamati dengan menggunakan alat pengelihatan. Pada umumnya siswa lebih mudah belajar dengan melihat sesuatu yang sedang dibahas dalam pembelajaran, terutama siswa SD yang masih berada pada tahap operasional konkrit masih sulit untuk berpikir abstrak. Belajar secara visual juga dapat membantu siswa melihat inti dari suatu masalah, seperti mengamati gambar, membaca teks, menyimak sebuah tayangan video, serta menggambar; dan (4) Intellectualy, yaitu belajar dengan kemampuan berpikir dan memecahkan masalah. Belajar secara intelektual menekankan pada konsentrasi berpikir, menalar, menyelidiki, 
mengidentifikasi dan menerapkan ide dalam memecahkan masalah, menciptakan makna pribadi berdasarkan sebuah teori, serta menerapkan gagasan baru dalam suatu pekerjaan. Kusumawati (2018) mendukung teori model pembelajaran SAVI bahwa pembelajaran hendaknya terlaksana beberapa jenis kegiatan, seperti mendengar, melihat, hingga mengkreasikan karya berdasarkan kemampuan yang dimiliki. Pada hal ini, karakteristik model pembelajaran SAVI dapat mencakup seluruh aktivitas siswa dalam proses belajar, yang mana siswa tidak hanya memperoleh pengetahuan secara teori tetapi juga mengalami sendiri hal-hal yang sedang dipelajari.

Model pembelajaran SAVI memiliki empat tahap dalam pelaksanaan pembelajaran, yang diantaranya yaitu tahap persiapan, tahap penyampaian, tahap pelatihan, dan tahap penyampaian hasil (Shoimin, 2014). Tahap-tahap pada model pembelajaran SAVI memberikan kesempatan kepada siswa untuk terlibat secara langsung dalam proses pembelajaran dan mengontruksi pengetahuannya sendiri dengan memanfaatkan pikiran serta alat indra secara aktif. Kegiatan pembelajaran seperti ini sesuai dengan kebutuhan siswa sehingga mampu menumbuhkan minat dan hasil belajar siswa (Devitasari, 2019).

Setiap model pembelajaran memiliki keunggulan termasuk model model pembelajaran SAVI. Secara umum, model pembelajaran SAVI memiliki beberapa kelebihan seperti yang disebutkan Shoimin (2014), yaitu diantaranya, (1) membangkitkan kecerdasan siswa melalui penggabungan aktivitas fisik dan intelektual; (2) meningkatkan retensi sehingga tidak mudah lupa terhadap suatu konsep dikarenakan siswa membangun sendiri pengetahuannya; (3) menciptakan kegiatan belajar menyenangkan dan efektif dengan melibatkan siswa secara langsung dalam pembelajaran; (4) membangkitkan kreativitas dan kemampuan psikomotor siswa; (5) mengoptimalkan ketajaman pikiran dalam berkonsentrasi; (6) memotivasi siswa dalam belajar sesuai dengan gaya belajarnya masing-masing baik secara visual, auditori, maupun kinestetik; (7) melatih siswa untuk terbiasa terlibat aktif, berpikir kreatif, dan berani berpendapat. Kegiatan pembelajaran yang menarik bagi siswa sangat penting untuk menunjang proses pembelajaran, terlebih pada siswa yang berada di SD. Untuk mendukung proses pembelajaran, guru dapat menggunakan media yang bervariasi sesuai dengan kebutuhan materi pelajaran. Sebagai suatu komponen pembelajaran, media memiliki fungsi dan peran penting dalam keberlangsungan pembelajaran, salah satunya yaitu sebagai komponen yang memuat informasi pembelajaran. Pemilihan media yang sesuai dapat menjadikan proses pembelajaran lebih kondusif, efektif, efisien, dan dapat meningkatkan kualitas pembelajaran (Kariadnyani, 2016). Mengingat siswa belajar dengan gaya belajar yang berbeda-beda, guru dapat memilih multimedia sebagai alternatif untuk menyajikan informasi pembelajaran. Multimedia merupakan gabungan dari beberapa unsur seperti gambar, teks, grafik, audio, dan video yang dapat dihubungkan dengan link atau tool serta navigasi untuk mendukung aktivitas pembelajaran (Faizah \& Simamora, 2020). Pemanfaatan kombinasi unsur teks, audio, visual, dan video dalam menampilkan informasi pada multimedia memberikan pengalaman belajar yang mendekati realita. Multimedia menayangkan informasi dalam bentuk menyenangkan, kreatif, dan mudah dimengerti karena melibatkan beberapa alat indra, seperti mata dan telinga untuk menyimak informasi (Sabillah, 2019). Tayangan multimedia digunakan secara efektif dalam pembelajaran yang menerapkan metode pembelajaran seperti presentasi, demonstrasi, latihan berulang, pemecahan masalah dan simulasi (Pribadi, 2017). 
Multimedia mempunyai manfaat dalam pembelajaran yaitu dapat menarik minat siswa untuk mengikuti kegiatan belajar, meningkatkan pola interaksi, serta dapat menjaga kualitas pembelajaran. Selain itu, dikutip dari Henich dan Mondela (dalam Pribadi, 2017:163), terdapat beberapa keunggulan multimedia sebagai media pembelajaran, yang meliputi: (1) meningkatkan daya ingat atau retensi siswa; (2) memfasilitasi siswa dengan gaya belajar berbeda; (3) membantu siswa mencapai tujuan pembelajaran secara efektif; (4) menyajikan informasi dengan tingkat realisme tinggi; (5) meningkatkan semangat belajar siswa; (6) dapat digunakan untuk mendukung aktivitas belajar baik individual maupun kelompok; (7) menampilkan materi pelajaran secara konsisten. Penggunaan multimedia memudahkan guru dalam menyalurkan informasi karena dibantu oleh beberapa media sehingga dapat merangsang pikiran dan perhatian siswa dalam pembelajaran (Antari et al., 2017). Dari pemaparan tersebut, dapat dinyatakan bahwa multimedia baik diterapkan sebagai media pembelajaran untuk mempertinggi interaksi siswa dalam konteks yang dipelajari. Hal itu dikarenakan penggunaan multimedia lebih efektif jika dibandingkan dengan menggunakan satu media, seperti gambar saja atau suara saja (Mulia, 2019).

Adanya hasil penelitian yang telah dilaksanakan sebelumnya turut mendukung penelitian ini. Seperti hasil penelitian yang dilakukan oleh Wardani (2017) yang menyimpulkan bahwa model pembelajaran SAVI dapat meningkatkan hasil belajar IPA siswa kelas V SD Negeri 2 Cihonje yang ditunjukkan dengan peningkatan hasil belajar siswa. Hal serupa juga disebutkan oleh Dewi et al., (2019) dalam hasil penelitiannya yang menyatakan bahwa terdapat perbedaan hasil belajar IPS antara siswa yang dibelajarkan dengan model pembelajaran SAVI dan siswa yang tidak dibelajarkan dengan model pembelajaran SAVI. Siswa yang mengikuti pembelajaran dengan model pembelajaran SAVI memperoleh hasil belajar lebih tinggi dibandingkan dengan siswa yang tidak dibelajarkan dengan model pembelajaran SAVI. Selain itu, Kartikasari (2016) dalam hasil penelitiannya menyatakan bahwa terdapat pengaruh yang signifikan pada penggunaan media pembelajaran berbasis multimedia terhadap hasil belajar siswa. Sehingga, penerapan model pembelajaran SAVI berbantuan multimedia cocok diterapkan pada muatan materi IPA, karena memiliki keunggulan mengaktifkan suasana belajar baik secara jasmani maupun intelektual. Dengan demikian, siswa secara keseluruhan dapat membangun pemahamannya sendiri berdasarikan pola pembelajaran yang disajikan oleh guru dalam memperoleh pengalaman belajar. Interaksi secara langsung antara siswa dan lingkungan belajarnya dapat mengaktifkan siswa dalam pembelajaran yang berdampak pada optimalnya hasil belajar (Amalia et al., 2020).

Dari informasi yang telah dipaparkan, penelitian ini bertujuan untuk menganalisis pengaruh model pembelajaran SAVI berbantuan multimedia terhadap kompetensi pengetahuan IPA kelas V SD Negeri Gugus Dr. Soetomo Denpasar Selatan tahun ajaran 2019/2020.

\section{METODE PENELITIAN}

Penelitian dilaksanakan di Gugus Dr. Soetomo Denpasar Selatan pada bulan Februari sampai dengan April 2020. Penelitian ini menggunakan pendekatan kuantitatif, dengan jenis penelitian eksperimen berbentuk Quasi Experimental Design atau eksperimen semu. Adapun rancangan eksperimen yang digunakan adalah Non-equivalent Posttest Only Control Group Design. 
Prosedur penelitian yang dilalui dalam penelitian ini meliputi 3 tahapan, yaitu tahap persiapan, tahap pelaksanaan, dan tahap akhir penelitian. Pada tahap persiapan penelitian, terlebih dahulu mengadakan atau mempersiapkan hal-hal seperti, (a) wawancara terkait penelitian; (b) penyusunan Rancangan Pelaksanaan Pembelajaran (RPP); (c) mendiskusikan RPP bersama dosen pembimbing dan wali kelas; (d) menyiapkan perangkat perangkat pendukung, yakni multimedia sebagai media pembelajaran, serta (e) Mendiskusikan instrumen penelitian untuk pengumpulan data bersama dosen pembimbing dan wali kelas. Pada tahap pelaksanaan penelitian dilakukan pemberian perlakuan sebanyak 6 kali kepada kelompok eksperimen dengan model pembelajaran SAVI berbantuan multimedia, sedangkan kelompok kontrol tetap dibelajarkan secara konvensional. Pada akhir penelitian diberikan posttest untuk mengukur kompetensi pengetahuan IPA pada kedua kelompok, kemudian dilanjutkan dengan pengolahan data.

Populasi dalam penelitian ini adalah seluruh siswa kelas V SD Negeri Gugus Dr. Soetomo Denpasar Selatan tahun ajaran 2019/2020 yang secara keseluruhan berjumlah 226 siswa dari 6 kelas dalam 4 sekolah. Setelah menentukan populasi penelitian, selanjutnya menetapkan anggota sampel penelitian untuk mewakili penelitian. Teknik sampling yang digunakan untuk menentukan sampel dalam penelitian ini adalah cluster random sampling atau sampel kelompok. Pengacakan yang dilakukan adalah pengacakan kelas. Pengacakan dilakukan dengan mengadakan pengundian sebanyak dua kali. Pengundian pertama dilakukan dengan mengundi masing-masing kelas hingga didapatkan dua kelas sebagai sampel penelitian. Sebelum menentukan kelompok eksperimen dan kelompok kontrol, anggota sampel penelitian diberikan tes uji kesetaraan terlebih dahulu yang bertujuan untuk mengetahui kesetaraan sampel secara akademik. Selanjutnya, pengundian kedua dilakukan untuk menentukan kelas yang menjadi kelompok eksperimen dan kelompok kontrol. Berdasarkan hasil pengundian diperoleh kelas V SD Negeri 4 Sesetan dengan 39 siswa sebagai kelompok eksperimen dan kelas V SD Negeri 14 Sesetan dengan 37 siswa sebagai kelompok kontrol.

Pada penelitian terdapat kontrol validitas internal dan eksternal. Validitas internal dalam penelitian ini meliputi: (1) sejarah, yaitu berkenaan dengan pembentukan kelas, kurikulum dan tingkat pendidikan guru kelas. Kelompok sampel, yakni kelas V SD Negeri 4 Sesetan dan kelas V SD Negeri 14 Sesetan dibelajarkan menggunakan kurikulum yang sama, yaitu kurikulum 2013 dan diampu oleh guru kelas yang sama-sama dengan pendidikan terakhir S1. Pembentukan kelas pada kedua kelompok tersebut tidak dibentuk secara khusus, yang mana tidak ada kelas unggulan; (2) Bias seleksi, yaitu berkaitan dengan cara pemilihan kelompok eksperimen dan kelompok kontrol. Sebelum ditentukan kelompok eksperimen dan kelompok kontrol, sampel penelitian diberikan tes uji kesetaraan terlebih dahulu untuk mengetahui kesetaraan sampel sehingga perubahan kompetensi pengetahuan terjadi karena adanya perlakuan, bukan karena perbedaan antarsubjek; (3) Kematangan, yaitu berkaitan dengan perubahan subjek. Waktu menjadi salah satu faktor yang mempengaruhi kematangan sehingga memiliki pengaruh terhadap hasil eksperimen. Pengendalian terhadap faktor ini dilakukan dengan memberikan perlakuan sebanyak 6 kali sehingga kompetensi pengetahuan IPA dapat mengalami perubahan serta menggunakan kelompok kontrol sebagai kelompok pembanding. Sementara itu, validitas eksternal berkaitan dengan faktor luar yang mempengaruhi penelitian. Terdapat beberapa ancaman yang berkaitan dengan validitas eksternal, diantaranya, (1) interaksi antara perlakuan dan latar, berkaitan dengan subjek dalam penelitian bertindak berbeda dengan subjek yang 
diharapkan. Untuk mengendalikan ancaman tersebut dapat dilakukan dengan membatasi populasi dan menentukan sampel untuk mewakili penelitian; (2) Interaksi antara perlakuan dan latar, yakni berkaitan dengan lingkungan dan situasi eksperimen. Ancaman ini dapat dikendalikan dengan melibatkan guru secara langsung dalam pembelajaran dan tidak memberitahu siswa bahwa dirinya sedang terlibat dalam penelitian.

Pengumpulan data pada penelitian ini dilakukan dengan metode tes. Tes yang digunakan untuk mengumpulkan data kompetensi pengetahuan IPA berupa posttest yang diberikan kepada anggota sampel penelitian. Instrumen pengumpulan data yang digunakan adalah tes objektif dalam bentuk pilihan ganda (multiple choice). Instrumen posttest terdiri dari 36 butir tes yang disertai dengan empat alternatif jawaban, yaitu (a, b, c, dan d) sebelumnya telah melalui uji validasi oleh dua pakar dan uji validasi empirik yang meliputi uji validitas, uji reliabilitas, uji tingkat kesukaran dan uji daya beda.

Data kompetensi pengetahuan IPA yang dikumpulkan dianalisis menggunakan teknik analisis data yaitu statistik deskriptif dan statistik inferensial. Statistik deskriptif yang digunakan untuk menggambarkan data kompetensi pengetahuan IPA adalah rata-rata (mean), standar deviasi dan varians. Sementara, analisis statistik inferensial digunakan untuk menguji hipotesis penelitian yaitu menggunakan uji-t dengan rumus polled varians yang sebelumnya dilakukan uji prasyarat analisis, yaitu uji normalitas sebaran data dan uji homogenitas varians.

\section{HASIL DAN PEMBAHASAN}

\section{HASIL DAN PEMBAHASAN}

Data yang dianalisis dalam penelitian ini adalah data kompetensi pengetahuan IPA kelas V tema 7 (Peristiwa dalam Kehidupan) yang diperoleh dari hasil posttest. Hasil dalam penelitian ini meliputi deskripsi data kompetensi pengetahuan IPA kelompok eksperimen dan deskripsi data kompetensi pengetahuan IPA kelompok kontrol. Berdasarkan hasil pemberian 36 butir soal, kelompok eksperimen yang terdiri dari 39 siswa memperoleh skor maksimum $=97$ dan skor minimum $=61$ dengan skor rata-rata $=81,14$. Sedangkan, kelompok kontrol yang terdiri dari 37 siswa memperoleh skor maksimum $=92$ dan skor minimum $=50$ dengan skor rata-rata $=72,43$. Adapun frekuensi skor posttest kelompok eksperimen dapat dilihat pada grafik poligon berikut.

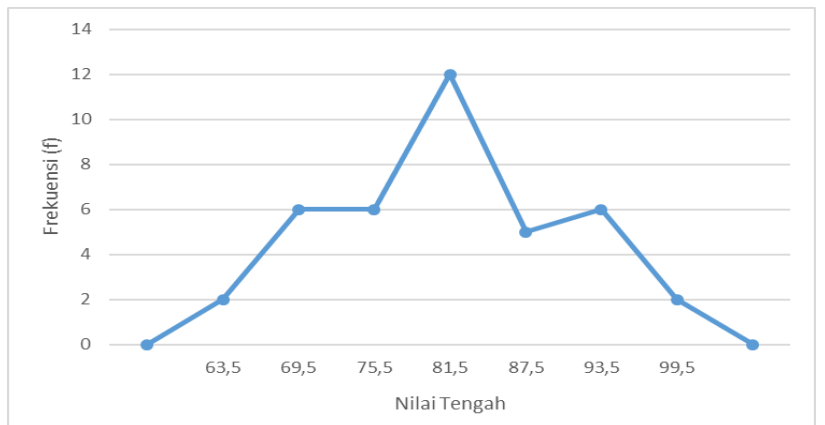

Gambar 2. Grafik poligon data posttest kelompok eksperimen

Berdasarkan grafik pada gambar 2, diketahui bahwa sebanyak 2 siswa dengan frekuensi relatif 5,13\% memperoleh skor pada interval 61-66, 6 siswa dengan frekuensi relatif $15,38 \%$ memperoleh skor pada interval 67-72, 6 siswa dengan frekuensi relatif 15,38\% memperoleh skor pada interval 73-78, 12 siswa dengan frekuensi relatif 30,77\% 
memperoleh skor pada interval 79-84, 5 siswa dengan frekuensi relarif 12,82\% memperoleh skor pada interval 85-90, 6 siswa dengan frekuensi relatif 15,38\% memperoleh skor pada interval 91-96, dan 2 siswa dengan frekuensi relatif 5,13\% memperoleh skor pada interval 97-102. Dapat dilihat data terbanyak terletak pada nilai tengan 81,5 dengan interval 79-84 sebanyak 12 siswa. Sementara itu, frekuensi skor posttest kelompok kontrol dapat dilihat pada grafik poligon berikut.

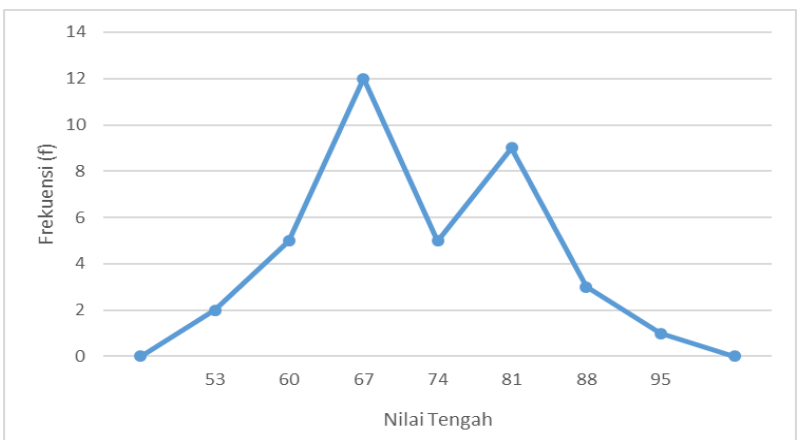

Gambar 3. Grafik Grafik poligon data posttest kelompok control

Berdasarkan grafik pada gambar 3, diketahui bahwa sebanyak 2 siswa dengan frekuensi relatif 5,40\% memperoleh skor pada interval 50-56, 5 siswa dengan frekuensi relatif $13,51 \%$ memperoleh skor pada interval 57-63, 12 siswa dengan frekuensi relatif $32,43 \%$ memperoleh skor pada interval 64-70, 5 siswa dengan frekuensi relatif 13,51\% memperoleh skor pada interval 71-77, 9 siswa dengan frekuensi relarif 24,32\% memperoleh skor pada interval 78-84, 3 siswa dengan frekuensi relatif 8,11\% memperoleh skor pada interval 85-91, dan 1 siswa dengan frekuensi relatif 2,70\% memperoleh skor pada interval 92-98. Dapat dilihat data terbanyak terletak pada nilai tengah 67 dengan interval 64-70 sebanyak 12 siswa.

Selanjutnya, dilakukan pengujian hipoteisis menggunakan uji-t dengan rumus polled varians. Namun, sebelum melakukan uji hipotesis, terlebih dahulu dilakukan uji prasyarat analisis yang meliputi uji normalitas sebaran data dan uji homogenitas varians pada kedua kelompok.

Uji normalitas sebaran data dilakukan dengan rumus Kolmogorov-Smirnov untuk mengetahui data berdistribusi normal atau tidak dengan kriteria pengujian yaitu apabila nilai maksimum $|\mathrm{ft}-\mathrm{fs}|<$ nilai tabel Kolmogorov-Smirnov pada taraf signifikansi 5\%, maka data dinyatakan berdistribusi normal. Sebaliknya, apabila nilai maksimum $|\mathrm{ft}-\mathrm{fs}|>$ nilai tabel Kolmogorov-Smirnov pada taraf signifikansi 5\%, maka data dinyatakan tidak berdistribusi normal. Hasil uji normalitas sebaran data posttest disajikan pada tabel 1.

Tabel 1 Rekapitulasi Hasil Uji Normalitas Sebaran Data Posttest

\begin{tabular}{llccc}
\hline \multicolumn{2}{c}{ Sampel Penelitian } & $\begin{array}{c}\text { Nilai } \\
\text { Maksimum } \\
|\mathrm{ft}-\mathrm{fs}|\end{array}$ & $\begin{array}{c}\text { Nilai tabel } \\
\text { Kolmogorov- } \\
\text { Smirnov }\end{array}$ & Keterangan \\
\hline Kelompok Eksperimen & 39 siswa & 0,09 & 0,21 & Berdistribusi normal \\
Kelompok Kontrol & 37 siswa & 0,11 & 0,22 & Berdistribusi normal \\
\hline
\end{tabular}


Bedasarkan tabel 1 diketahui nilai maksimum $|\mathrm{ft}-\mathrm{fs}|$ kelompok eksperimen $=0,09$, sedangkan nilai tabel Kolmogorov-Smirnov $=0,21$. Hal tersebut menunjukkan bahwa nilai maksimum $|\mathrm{ft}-\mathrm{fs}|<$ nilai tabel Kolmogorov-Smirnov $(0,09<0,21)$ yang artinya data berdistribusi normal. Kemudian, dari hasil pengujian terhadap data kompetensi pengetahuan IPA kelompok kontrol diperoleh nilai maksimum $|\mathrm{ft}-\mathrm{fs}|=0,11$, sedangkan nilai tabel Kolmogorov-Smirnov = 0,22. Hal tersebut menunjukkan bahwa nilai maksimum $|\mathrm{ft}-\mathrm{fs}|<$ nilai tabel Kolmogorov-Smirnov $(0,11<0,22)$ yang artinya data berdistribusi normal.

Setelah diketahui data kedua kelompok berdistribusi normal, selanjutnya dilakukan uji homogenitas varians. Uji homogenitas varians dilakukan menggunakan uji-F dengan kriteria pengujian, apabila Fhitung < Ftabel pada taraf signifikansi 5\%, maka data dinyatakan homogen. Sebaliknya, apabila Fhitung > Ftabel pada taraf signifikansi 5\%, maka data dinyatakan tidak homogen. Hasil uji homogenitas varians data posttest disajikan dalam tabel berikut.

Tabel 2 Rekapitulasi Hasil Uji Homogenitas V Data Posttest

\begin{tabular}{lccccc}
\hline \multicolumn{1}{c}{ Sampel Penelitian } & $\mathrm{dk}=\mathrm{n}-1$ & $\mathrm{~s}^{2}$ & $\mathrm{~F}_{\text {hitung }}$ & $\mathrm{F}_{\text {tabel }}$ & Keterangan \\
\hline Kelompok Eksperimen & 38 & 93,43 & \multirow{2}{*}{1,02} & 1,72 & Homogen \\
Kelompok Kontrol & 36 & 91,83 & & & \\
\hline
\end{tabular}

Dari tabel 2 diketahui bahwa nilai Ftabel adalah 1,72, sedangkan nilai Fhitung adalah 1,02. Sehingga, Fhitung lebih kecil dari Ftabel $(1,02<1,72)$, yang artinya kedua kelompok memiliki varians yang homogen.

Berdasarkan hasil uji prasyarat analisis diketahui bahwa data kedua kelompok berdistribusi normal dan memiliki varians yang homogen, maka selanjutnya dapat dilakukan pengujian hipotesis untuk menjawab rumusan masalah pada penelitian menggunakan uji-t dengan rumus polled varians. Kriteria yang berlaku yaitu apabila thitung $>$ ttabel, maka H0 ditolak dan Ha diterima. Sebaliknya, apabila thitung $\leq$ ttabel maka $\mathrm{H} 0$ diterima dan Ha ditolak. Adapun rekapitulasi hasil pengujian hipotesis disajikan dalam tabel 3 berikut.

Tabel 3 Rekapitulasi Hasil Uji Hipotesis

\begin{tabular}{lcccccc}
\hline \multicolumn{1}{c}{ Sampel Penelitian } & Rata-rata & Varians & $\mathrm{Dk}$ & $\mathrm{t}_{\text {hitung }}$ & $\mathrm{t}_{\text {tabel }}$ & Simpulan \\
\hline Kelompok Eksperimen & 81,14 & 93,43 & \multirow{2}{*}{74} & 4,51 & 2,00 & $\mathrm{H}_{0}$ ditolak \\
Kelompok Kontrol & 72,43 & 91,83 & & & & \\
\hline
\end{tabular}

Dari tabel 3 diketahui bahwa perolehan thitung $=4,51$ sedangkan ttabel $=2,00$ yang artinya thitung $>$ ttabel $(4,51>2,00)$ sehingga $\mathrm{H} 0$ yang menyatakan "tidak terdapat perbedaan yang signifikan kompetensi pengetahuan IPA antara kelompok yang dibelajarkan dengan model pembelajaran SAVI berbantuan multimedia dan kelompok yang dibelajarkan dengan pembelajaran konvensional pada kelas V SD Negeri Gugus Dr. Soetomo Denpasar Selatan Tahun Ajaran 2019/2020" ditolak dan Ha yang menyatakan 
"terdapat pengaruh yang signifikan model pembelajaran SAVI berbantuan multimedia terhadap kompetensi pengetahuan IPA kelas V SD Negeri Gugus Dr. Soetomo Denpasar Selatan tahun ajaran 2019/2020" diterima. Dengan demikian, hasil penelitian ini membuktikan bahwa terdapat pengaruh yang signifikan model pembelajaran SAVI berbantuan multimedia terhadap kompetensi pengetahuan IPA kelas V SD Negeri Gugus Dr. Soetomo Denpasar Selatan tahun ajaran 2019/2020.

Kegiatan pembelajaran pada kelompok eksperimen dengan model pembelajaran SAVI berbantuan multimedia berjalan dengan baik dan kondusif. Siswa antusias mengikuti pelajaran yang terlihat aktif dan semangat ketika melakukan percobaan maupun menyimak multimedia. Siswa tidak hanya mengandalkan informasi yang disampaikan oleh guru, tetapi sudah lebih sering bertanya dan mengemukakan pendapat. Siswa juga terlihat semangat dalam melakukan percobaan sederhana yang sebelumnya sangat jarang dilaksanakan. Suasana belajar pada kelompok eksperimen memberikan kesempatan kepada siswa untuk membangun sendiri pemahamannya, bukan hanya sebagai penerima informasi dari guru yang kemudian dihafalkan. Hal tersebut dikarenakan langkah-langkah model pembelajaran SAVI dapat melatih siswa untuk belajar dengan berbagai gaya belajar, seperti melihat dan mengamati, mendengar dan berbicara, melakukan sesuatu seperti percobaan sederhana serta berlatih untuk memecahkan masalah dengan penalaran dan proses berpikir. Hal tersebut sejalan dengan temua pada hasil penelitian yang dilakukan oleh (Fitriyani, 2015) bahwa model pembelajaran SAVI dapat meningkatkan rasa ingin tahu siswa, kemampun bertanya dan mengungkapkan argumen, melatih kemampuan berpikir serta mengevaluasi pengetahuan berdasarkan bukti, seperti praktikum sehingga mejadikan suasana belajar menjadi menyenangkan. Puspitasari (2018) juga menjelaskan penggunaan model pembelajaran SAVI dapat mengoptimalkan aktivitas panca indra dan pikiran sehingga siswa tidak hanya diam mendengarkan penjelasan guru, sehingga cocok untuk semua gaya belajar siswa. Selain itu, pada penelitiannya juga jelaskan bahwa model pembelajaran SAVI membawa dampak positif terhadap hasil belajar IPA, khususnya pada ranah kognitif.

Berbeda halnya dengan pembelajaran pada kelompok kontrol yang dibelajarkan dengan pembelajaran konvensional, suasana belajar terkesan monoton dan masih berlangsung satu arah. Oleh karena itu, dalam pembelajaran siswa mudah bosan dan kurang antusias dalam belajar. Siswa yang hanya sebagai penerima informasi tidak dapat memberikan perhatian dan berkosentrasi dalam jangka waktu yang lama untuk memperhatikan guru menjelaskan materi di depan kelas sehingga menunjukkan sikap lainlain dan bercanda bersama teman. Meskipun ditengah-tengah pembelajaran diadakan diskusi kelompok, namum masih seperti pada saat observasi di awal kegiatan, hanya beberapa siswa yang giat untuk mengerjakan tugas, sementara siswa lainnya dalam kelompok masih pasif dan hanya mengandalkan satu orang saja. Kurangnya pemanfaatan media pembelajaran dan kegiatan pembelajaran seperti percobaan juga berpengaruh pada aktivitas siswa dalam belajar. Hal serupa juga dijelaskan dala temuan penelitian Putri (2017), bahwa pembelajaran konvensional terkesan monoton yang menyebabkan siswa kurang bersemangat dalam belajar sehingga berdampak pada kompetensi pengetahuan IPA siswa.

Berdasarkan hasil temuan tersebut, dapat dinyatakan kedua kelompok yang pada awalnya memiliki kemampuan setara secara akademik, namun setelah diberikan perlakuan yang berbeda, kompetensi pengetahuan IPA kedua kelompok juga mengalami perbedaan 
yang signifikan. Perbedaan tersebut diakibatkan oleh penerapan model pembelajaran SAVI berbantuan multimedia yang diterima oleh kelompok eksperimen. Model pembelajaran SAVI mengakibatkan siswa secara keseluruhan dapat mengikuti pembelajaran sesuai dengan gaya belajarnya masing-masing dengan memanfaatkan aktivitas alat indra dan intelektual, sehingga suasana pembelajaran menjadi lebih aktif dan menyenangkan karena siswa tidak hanya sebagai pendengar dalam pembelajaran, tetapi membangun pemahamannya sendiri melalui kegiatan percobaan dan diskusi dalam memecahkan masalah. Temuan penelitian ini didukung oleh pendapat Meier (2012) bahwa menggabungkan gerak fisik dengan aktivitas intelektual dapat berpengaruh terhadap pembelajaran. Hal lainnya yang mendukung proses pembelajaran pada kelompok eksperimen adalah bantuan multimedia yang diterapkan pada model pembelajaran SAVI. Multimedia memberikan nuansa yang menarik bagi siswa karena merupakan gabungan dari unsur teks, gambar, audio, dan video yang dikemas dan disajikan dengan proyektor di depan kelas. Dalam pembelajaran, siswa semangat dan fokus menyimak multimedia yang ditayangkan guru. Hal tersebut tentunya meminimalisir aktivitas siswa seperti lain-lain, mengantuk dan ribut pada saat pembelajaran. Multimedia juga memiliki karakteristik yang dapat mencakup hampir seluruh gaya belajar siswa, sehingga siswa dapat mengikuti pembelajaran dengan baik. Sejalan dengan pendapat Kartikasari (2016), bahwa media pembelajaran berbasis multimedia dapat meningkatkan motivasi dan hasil belajar siswa.

Sehingga penerapan model pembelajaran SAVI berbantuan multimedia baik diterapkan untuk menciptakan suasana belajar aktif dan menyenangkan, serta melatih kemampuan fisik maupun intelektual sehingga dapat meningkatkan kompetensi pengetahuan siswa.

Kegiatan pembelajaran dengan model pembelajaran SAVI berbantuan multimedia sangat tepat untuk diterapkan, karena model pembelajaran SAVI dapat mengaktifkan suasana pembelajaran dengan kegiatan-kegiatan yang melibatkan unsur somatik, auditori, visual dan intelektual. Tahap-tahap pada model pembelajaran SAVI juga sangat mendukung optimalnya proses pembelajaran untuk mencapai tujuan yang diharapkan, khususnya pada muatan materi IPA. Pada tahap awal yaitu tahap persiapan, siswa diberikan stimulus oleh guru tentang apa yang akan dipelajari melalui kegiatan tanya jawab atau mengamati. Kedua yaitu tahap penyampaian, pada penelitian ini siswa diberikan kesempatan untuk menyimal multimedia dan mengumpulkan informasi secara mandiri sesuai dengan gaya belajarnya masing-masing. Ketiga yaitu tahap pelatihan, siswa bersama anggota kelompok untuk melakukan percobaan sederhana sesuai materi yang dipelajari. Pada saat diskusi, siswa dapat belajar lebih efektif dikarenakan kemampuan siswa satu dengan siswa lainnya tentu saja berbeda, sehingga dalam kelompok tersebut dapat saling melengkapi dan membantu. Sikap kerjasama juga sangat terlihat pada saat melakukan percobaan dan merumuskan hasil percobaan. Terakhir yaitu tahap penyampaian hasil, yang mana pada tahap ini siswa menyampaikan hasil diskusi di depan kelas yang selanjutnya ditanggapi oleh kelompok lain dan guru. Pada saat penyampaian hasil, siswa mulai lebih banyak berpendapat ataupun menyanggah apabila terjadi perbedaan yang ditemukan. Dan pada saat diberikan pertanyaan, siswa dapat menjawab pertanyaan tersebut dengan lebih lancar dengan bahasa dan pemahamannya sendiri, tidak sebatas menghafal. Kegiatan belajar tersebut membuktikan bahwa siswa dapat memahami materi pelajaran dengan baik. Pemahaman terhadap suatu materi yang dimiliki oleh siswa berdampak positif terhadap kompetensi pengetahuan yang semakin meningkat. 
Dibandingkan dengan pembelajaran konvensional dalam meningkatkan kompetensi pengetahuan IPA siswa, model pembelajaran SAVI memiliki banyak keunggulan yaitu, (1) model pembelajaran SAVI dapat mengaktifkan pemanfaatan alat indra baik fisik maupun psikis dalam kegiatan pembelajaran; (2) siswa tidak semata-mata memperoleh pengetahuan yang telah didengar ataupun dilihat, tetapi juga dapat menerapkannya dalam memecahkan maslah; (3) menumbuhkan kreativitas siswa dalam belajar (Cemara \& Sudana, 2019). Sejalan dengan pendapat Putra et al., (2016) bahwa model pembelajaran SAVI menekankan pada aktivitas pembelajaran dengan melibatan alat indra sebanyak mungkin yang mengakibatkan fisik dan pikiran aktif dalam pembelajaran sehingga siswa dapat memperoleh pengalaman belajar secara langsung. Kegiatan tersebut sangat cocok diterapkan dalam muatan materi IPA untuk menciptakan suasana belajar yang bermakna. Interaksi secara langsung antara siswa dan lingkungan belajarnya dapat mengaktifkan siswa dalam pembelajaran yang berdampak pada optimalnya hasil belajar (Amalia et al., 2020).

Penelitian ini dipertegas oleh hasil penelitian yang dilakukan oleh Sulaksana et al., (2018) yang menyatakan bahwa, terdapat perbedaan yang signifikan hasil belajar IPA antara kelompok yang mengikuti pembelajaran dengan model pembelajaran SAVI berbantuan LKS dan kelompok yang mengikuti pembelajaran konvensional pada siswa kelas V SD di Gugus III Kecamatan Kintamani Kabupaten Bangli tahun pelajaran 2017/2018. Sutarna (2018) menyimpulkan bahwa model pembelajaran SAVI berpengaruh untuk meningkatkan kemampuan bertanya dan mengemukakan pendapat, meningkatkan kemampuan berfikir kristis siswa dan meningkatkan hasil belajar siswa kelas IV Sekolah Dasar Negeri Cimulya pada mata pelajaran Ilmu Pengetahuan Sosial (IPS) tentang masalah sosial. Selain itu, (Karwati, 2018) menyimpulkan bahwa model pembelajaran Probing Promting berbantuan multimedia berpengaruh terhadap hasil belajar IPA siswa kelas V SD Gugus I Kecamatan Kuta Utara tahun ajaran 2017/2018. Jadi, model pembelajaran SAVI berbantuan multimedia dapat diterapkan pada mata pelajaran di SD termasuk IPA pada aspek kognitif untuk meningkatkan kompetensi pengetahuan siswa.

Berdasarkan hal tersebut, model pembelajaran SAVI berbantuan multimedia perlu dikembangkan dalam pembelajaran untuk menciptakan suasana belajar aktif, menarik dan menyenangkan yang dapat berdampak pada kompetensi pengetahuan siswa.

\section{SIMPULAN}

Berdasarkan hasil analisis dan pengujian hipotesis, terdapat perbedaan yang signifikan kompetensi pengetahuan IPA antara kelompok yang dibelajarkan dengan model pembelajaran SAVI berbantuan multimedia dan kelompok yang dibelajarkan dengan pembelajaran konvensional pada kelas V SD Negeri Gugus Dr. Soetomo Denpasar Selatan Tahun Ajaran 2019/2020. Hal ini dapat disimpulkan bahwa terdapat pengaruh yang signifikan model pembelajaran SAVI berbantuan multimedia terhadap kompetensi pengetahuan IPA kelas V SD Negeri Gugus Dr. Soetomo Denpasar Selatan tahun ajaran 2019/2020.

\section{DAFTAR PUSTAKA}

Adnyana, I. K. W S., dkk. (2017). "Pengaruh Model Pembelajaran Kooperatif Tipe Talking Stick Terhadap Kompetensi Pengetahuan IPA Siswa Kelas V SD Gugus Kapten Kompyang Sujana". e-Journal PGSD Universitas Pendidikan Ganesha Mimbar 
PGSD, Volume 5, Nomor 3 (hlm. 1-11).

Agustino, I. K., dkk. (2017). "Pengaruh Model Pembelajaran Inkuiri Berbasis Penilaian Kinerja Terhadap Kompetensi Pengetahuan IPA Siswa Kelas IV Gugus IX Abiansemal Kecamatan Abiansemal Tahun Pelajaran 2016/2017'. e-Journal PGSD Universitas Pendidikan Ganesha Mimbar PGSD, Volume 5, Nomor 3 (hlm. 1-9).

Amalia, M., dkk. (2020). "Pengaruh Model Pembelajaran SAVI Terhadap Hasil Belajar IPA Kelas V”. Jurnal Pendidikan Fisika dan Sains, Volume 3, Nomor 1 (hlm. 1-5).

Antari, Ni Luh Putu Yuni. 2017. "Pengaruh Model Pembelajaran Kooperatif Tipe Two Stay Two Stray (TSTS) Berbantuan Multimedia Terhadap Kompetensi Pengetahuan IPS Siswa Kelas V SD Gugus Letda Made Putra". e-Journal PGSD Universitas Pendidikan Ganesha Mimbar PGSD, Volume 5, Nomor 2 (hlm. 1-10).

Arisantiani, N. K., dkk. (2017). "Pengaruh Model Pembelajaran Childrens Learning in Science (CLIS) Berbantuan Media Lingkungan Terhadap Kompetensi Pengetahuan IPA". Jornal of Education Technology, Volume 1, Nomor 2 (hlm. 124-132).

Budiyanti, Yudi \& Khairunnisa. 2019. "Upaya Meningkatkan Pemahaman Konsep melalui Model Pembelajaran Somatic, Auditory, Visualization, Intellectualy pada Mata Pelajaran IPA Siswa Kelas V MI Mifftahul Huda Kota Bekasi”. Pedagogik, Volume VII, Nomor 2 (hlm. 13-19).

Candra, Anak Agung Bagus Trisna Adi, dkk. 2017. "Pengaruh Model Discovery Learning Terhadap Kompetensi Pengetahuan IPA Siswa Kelas VI SD Gugus Yos Sudarso Kecamatan Denpasar Selatan Tahun Pelajaran 2016/2017". e-Journal PGSD Universitas Pendidikan Ganesha Mimbar PGSD, Volume 5, Nomor 2 (hlm. 1-10).

Cemara, G. A. G., \& Sudana, D. N. (2019) "Pengaruh Model Pembelajaran SAVI Bermuatan Peta Pikiran Terhadap Kreativitas dan Penguasaan Kompetensi Pengetahuan IPA Siswa". Jurnal Ilmiah Sekolah Dasar, Volume 3, Nomor 3 (hlm. 352-360).

Devitasari, Tiyas. 2019. "Keevektifan Model SAVI Terhadap Minat dan Hasil Belajar IPA SDN Lawatan 01 Kabupaten Tegal”. Indonesian Journal of Conservation, Volume 8, Nomor 1 (hlm. 35-40).

Dewi, M. R. S., dkk. (2019). "Pengaruh Model Pembelajaran SAVI (Somatic, Auditori, Visual dan Intelektual) Terhadap Keterampilan Berpikir Kritis IPA Siswa Sekolah Dasar". Mimbar PGSD Unsiksha, Volume 7, Nomor 1 (hlm. 22-28).

Faizah, O. N., \& Simamora, A. H. 2020. "Pengembangan Multimedia Pembelajaran IPA untuk Meningkatkan Hasil Belajar". Journal of Edication Technology, Volume 4, Nomor 1 (hlm. 52-58).

Fitriyani, dkk. (2015). "Pengaruh Model SAVI Terhadap Kemampuan Berpikir Kritis Dalam Mata Pelajaran IPA Kelas V SD". e-Journal PGSD Universitas Pendidikan Ganesha Mimbar PGSD, Volume 3, Nomor 1 (hlm. 1-12).

Indrawan, Kadek Andre. 2018. "Pengaruh Model Pembelajaran Somatic Auditory Visualization Intellectualy berbantuan Lingkungan Hidup Terhadap Hasil Belajar IPA Siswa Kelas IV SD Gugus Ir. Soekarno Denpasar Selatan Tahun Ajaran 2016/2017”. Jurnal Ilmiah Sekolah Dasar, Volume 2, Nomor 1 (hlm. 59-67). 
Kariadnyani, Kd Era. 2016. "Pengaruh Model Course Review Horay Berbantuan Multimedia Terhadap Hasil Belajar IPA Kelas V SD”. e-Journal PGSD Universitas Pendidikan Ganesha Mimbar PGSD, Volume 4, Nomor 1 (hlm. 1-12).

Kartikasari, Galuh. (2016). "Pengaruh Media Pembelajaran Berbasis Multimedia Terhadap Motivasi dan Hasil Belajar Materi Sistem Pencernaan Manusia". Dinamika Penelitian, Volume 16, Nomor 1 (hlm. 60-77).

Karwati, Ni Pt Rasni. 2018. "Pengaruh Model Pembelajaran Probing Prompting Berbantuan Multimedia Terhadap Hasil Belajar IPA Kelas V SD". Jurnal Ilmiah Pendidikan dan Pembelajaran, Volume 23, Nomor 2 (hlm. 335-345).

Kusumawati, Naniek. 2018. "Peningkatan Hasil Belajar Siswa Kelas V dengan Model Pembelajaran SAVI pada Mata Pelajaran IPA di SDN Mangkujayan I Kabupaten Ponorogo". Jurnal Pendidikan Dasar Nusantara, Volume 3, Nomor 2 (hlm. 217-224).

Meier, Dave. 2002. The Accelerated Learning Handbook (Panduan Kreatif \& Efektif Merancang Program Pendidikan dan Pelatihan). Bandung: Kaifa.

Mulia, Harpan Reski. 2019. "Pembelajaran Berbasis Multimedia: dalam Memahami Keberagaman Gaya Belajar Anak". Jurnal Penjaminan Mutu Lembaga Penjaminan Mutu Institut Hindu Dharma Negeri Denpasar, Volume 5, Nomor 2 (hlm. 144-154).

Pradnyana, I. G. B. A., dkk. 2017. "Pengaruh Model Problem Based Learning berbantuan Multimedia Terhadap Kompetensi Pengetahuan IPS Siswa Kelas IV SD Gugus I Gusti Ngurah Rai Denpasar Timur Tahun Pelajaran 2016/2017”. e-Journal PGSD Universitas Pendidikan Ganesha Mimbar PGSD, Volume 5, Nomor 2 (hlm. 1-10).

Pribadi, Benny A. 2017. Media \& Teknologi dalam Pembelajaran. Jakarta: Kencana.

Puspitasari, A., dkk. (2018). "Pengaruh Model Pembelajaran SAVI (Somatic, Auditory, Visualization, Intellectual) Dengan Media Hide and Seek Puzzle Terhadap Hasil belajar IPA". Jurnal Pendidikan, Volume 10, Nomor 2 (hlm. 137-148).

Putra, I. W. W. G., dkk. (2016). "Pengaruh Model Pembelajaran SAVI Bermuatan Tri Hita Karana Terhadap Hasil Belajar IPA Siswa Kelas IV". e-Journal PGSD Universitas Pendidikan Ganesha Mimbar PGSD, Volume 4, Nomor 1 (hlm. 1-9).

Putri, Putu Eka Cahya. 2017. "Pengaruh Model Pembelajaran Tipe Student Team Achievement Divisions Berbantuan Multimedia Terhadap Kompetensi Pengetahuan IPA Siswa Kelas IV SD Gugus Letda Made Putra". e-Journal PGSD Universitas Pendidikan Ganesha Mimbar PGSD, Volume 5, Nomor 2 (hlm. 1-9).

Ramadhan, M. I., dkk. 2016. "Penerapan Model PBL Berbantuan Multimedia untuk Meningkatkan Hasil Belajar Siswa pada Materi Daur Air dan Peristiwa Alam". Jurnal Pena Ilmiah, Volume 1, Nomor 1 (hlm. 721-730).

Sabillah, Bellona Mardhatillah. 2019. "Pengaruh Penggunaan Multimedia Pembelajaran Terhadap Hasil Belajar IPS di SD”. Jurnal Kajian Pendidikan Dasar, Volume 4, Nomor 2 (hlm. 700-708).

Samatowa. 2016. Pembelajaran IPA di Sekolah Dasar. Jakarta Barat: PT Indeks.

Setianingsih, I Gst. A. A. Aris. 2019. "Pengaruh Model Pembelajaran Reciprokal Teaching Berbantuan Media Audio Visual Terhadap Kompetensi Pengetahuan IPA". Journal of Education Technology, Volume 3, Nomor 3 (hlm. 203-209). 
Shoimin Aris. 2014. 86 Model Pembelajaran Inovatif dalam Kurikulum 2013. Yogjakarta: AR - RUZZ MEDIA.

Sihwinedar, Rinendah. 2015. "Meningkatkan Hasil Belajar IPA melalui Penerapan Model Pembelajaran SAVI (Somatic, Auditory, Visual, dan Intelektual) pada Siswa Kelas III SDN Rejoagung 01 Semboro". Pancaran, Volume 4, Nomor 4 (hlm. 138-148).

Sulaksana, Y. T. 2018. "Pengaruh Model Pembelajaran SAVI (Somatic Auditory Visualization Intellectualy) Berbantuan LKS Terhadap Hasil Belajar IPA". Jurnal Pedagogi dan Pembelajaran, Volume 1, Nomor 3 (hlm. 180-188).

Susanto, Ahmad. 2016. Teori Belajar dan Pembelajaran di Sekolah Dasar. Jakarta: Prenada Media Grup.

Sutarna, Nana. (2018). "Pengaruh Model Pembelajaran SAVI (Somatic Auditory Visual Intellectualy) Terhadap Hasil Belajar Siswa Kelas IV Sekolah Dasar". JPPD, Volume 5, Nomor 2 (hlm. 119-126).

Wardani, Fitrian Prila. 2017. "Penerapan Model Pembelajaran SAVI untuk Meningkatkan Hasil Belajar IPA Siswa Kelas V Sekolah Dasar". Jurnal Pancar, Volume 1, Nomor 2 (hlm. 5-8). 